Pesq. Vet. Bras. 37(12):1405-1410, dezembro 2017 DOI: $10.1590 / \mathrm{S} 0100-736 \mathrm{X} 2017001200008$

\title{
Oxidative state of ewes with different number of parity during gestation and lactation ${ }^{1}$
}

\author{
Teodulo Salinas Rios ${ }^{2}$, María Teresa Sánchez-Torres Esqueda ${ }^{3 *}$, Antonio Díaz \\ $\mathrm{Cruz}^{4}$, José Luis Cordero Mora ${ }^{3}$, Raquel Guinzberg Perrusquía ${ }^{5}$, José Leyver \\ Rabanales Morales ${ }^{3}$, José Luis Figueroa Velasco ${ }^{3}$ and Jorge Hernández Bautista ${ }^{2}$
}

\begin{abstract}
Salinas-Rios T., Sánchez-Torres Esqueda M.T., Díaz-Cruz A., Cordero-Mora J.L., Guinzberg-Perrusquía R., Rabanales-Morales J.L., Figueroa-Velasco J.L. \& Hernández-Bautista J. 2017. Oxidative state of ewes with different number of parity during gestation and lactation. Pesquisa Veterinaria Brasileira 37(12):1405-1410. Colegio de Postgraduados, Carretera México-Texcoco Km 36.5, Montecillo, Texcoco, Estado de México, 56230, México. E-mail: teresa@colpos.mx

This study was conducted to assess the changes in some indicators of oxidative status during pregnancy and lactation in sheep of different parity. Dorset $x$ Suffolk ewes were classified by number of parity: 1,2 and $\geq 4$. They were sampled before pregnancy and on the first, second, third, and fourth months, then on day 143 of pregnancy, as well as on day 5 after birth and after one month of lactation. Antioxidant capacity was found to have two reductions, the first during the second month of pregnancy and the second on day 5 of lactation. Susceptibility to lipid oxidation decreased with an increased number of parturitions. A reduction in lipid oxidation was observed on day 143 of gestation relative to the other samplings during gestation and lactation. Total glutathione peroxidase activity increased when the two reductions in antioxidant capacity took place. Ascorbic acid decreased during lactation and gestation; the lowest values were recorded in the third month of gestation. It is concluded that susceptibility to lipid oxidation decreases with the number of parturitions and that in ewes, during gestation and lactation, there is a mechanism that prevents lipid oxidation involving changes in antioxidant capacity, glutathione peroxidase and ascorbic acid.
\end{abstract}

INDEX TERMS: Ewes, sheep, parity, gestation, ascorbic acid, glutathione peroxidase, lipid oxidation, oxidative stress.

RESUMO.- [Estado oxidativo na gestação e lactação de ovelhas com diferentes números de partos.] Este estudo foi conduzido para avaliar as mudanças em alguns indica-

\footnotetext{
${ }^{1}$ Received on April 7, 2016.

Accepted for publication on May 2, 2017.

${ }^{2}$ Universidad Autónoma Benito Juárez de Oaxaca, FMVZ, Avenida Universidad s/n, Ex hacienda de Cinco Señores, Oaxaca de Juaréz, Oaxaca 68120, México. E-mails: salinas980@hotmail.com, jorgeherba@hotmail.com

${ }^{3}$ Colegio de Postgraduados, Carretera México-Texcoco Km 36.5, Montecillo, Texcoco, Estado de México, 56230, México. E-mails: cordero@colpos. mx, jley_3232@hotmail.com, jlfigueroa@colpos.mx *Corresponding author: teresa@colpos.mx Tel 015959520200 ext. 1705

${ }^{4}$ Departamento de Bioquímica, FMVZ Universidad Nacional Autónoma de México, Avenida Universidad 3000, Ciudad Universitaria, Coyoacán, Ciudad de México, Distrito Federal, 04510, México. E-mail: adc@unam.mx

${ }^{5}$ Departamento de Bioquímica, Facultad de Medicina, Universidad Nacional Autónoma de México, Avenida Universidad 3000, Ciudad Universitaria, Coyoacán, Ciudad de México, Distrito Federal, 04510, México. E-mail: guinzper@msn.com
}

dores do estado oxidativo durante a gestação e lactação em ovelhas com diferentes números de partos. Ovelhas Dorset $\mathrm{x}$ Sufolk foram classificadas pelo número de partos: 1 , 2 e $\geq 4$. Amostras foram coletadas antes da prenhez e no primeiro, segundo, terceiro e quarto mês e no dia 143 de gestação, assim como no dia 5 após o parto e com um mês de lactação. Encontrou-se que a capacidade antioxidativa teve duas reduções, a primeira durante o segundo mês de gestação e a segunda no dia 5 de lactação. A atividade total da glutationa peroxidase aumentou quando se deram as reduções de capacidade antioxidante. 0 ácido ascórbico diminuiu durante a gestação e lactação, com o valor mais baixo foi no terceiro mês de gestação. Conclui-se que a suscetibilidade a oxidação diminui com o número de partos, e que nas ovelhas durante a gestação e lactação há um mecanismo que previne a oxidação lipídica ocasionando mudanças na capacidade antioxidante, e das atividades glutationa peroxidase e ácido ascórbico. 
TERMOS DE INDEXAÇÃ0: Ovelhas, gestação, parto, ácido ascórbico, glutationa peroxidase, oxidação lipídica, estresse oxidativo.

\section{INTRODUCTION}

In the animal organism there is a system of enzyme and non-enzyme antioxidants (Al-Gubory et al. 2004) that helps achieve homeostasis. However, when the production of free radicals is greater than what the organism can counteract, a state of oxidative stress occurs (Agarwal et al. 2006). It has been demonstrated that oxidative stress causes disorders such as placenta retention (Brzezinska-Slebodzinsk et al. 1994), miscarriages, restriction of fetal growth, premature birth, and low birth weight (Al-Gubory et al. 2010), as well as a higher incidence of mastitis (Bouwstra et al. 2010). Thus, it is necessary to prevent it since it not only protects mothers during gestation, but may also improve the oxidative state of the offspring (Kamiloğlu et al. 2006).

Different studies have been conducted to determine the oxidative state in animals during gestation (Rezapour \& Taghinejad-Roudbaneh 2011), near parturition (Celi et al. 2010, Casamassima et al. 2012) and during lactation (Pedernera et al. 2010); these studies observed changes during these physiological states. It has also been observed that age is a factor that determines antioxidant capacity and lipid oxidation in sheep plasma (Salar-Amoli \& Baghbanzadeh 2010). It is necessary, however, to identify the beginning of these changes before breeding to determine when to supplement with antioxidants since, it has already been established that they aid in counteracting oxidative stress (Liu et al. 2013).

This study assessed four indicators of status oxidative. The first was Glutathione peroxidase (GSH-Px), the main enzymatic antioxidant that catalyzes reduction of hydrogen peroxide, helping to prevent oxidative damage (Arthur 2000). The second was vitamin C, which was assessed since it is believed that vitamin $C$ synthesis in ruminants is sufficient to satisfy requirements, and for this reason, supplementation is not a common practice in sheep production systems. However, in camels, it has been found that this vitamin undergoes changes in concentration during gestation and lactation (Mohamed et al. 2011). The third and fourth indicators evaluated were the total antioxidant capacity and lipoperoxidation, which measure the antioxidant potential and oxidation of blood plasma, which reflect the oxidative status of the animal. It is therefore necessary to determine these changes during lactation and gestation and their relationship with other indicators of the animal's oxidative status. Because ewes that have had different numbers of parturitions are found in a flock at different physiological states, it is necessary to determine whether the changes in oxidative state are also different. Thus, the objective of this experiment was to determine the changes in oxidative status during gestation and lactation of ewes with different number of parturitions and thus determine when sheep need to be supplemented with antioxidants.

\section{MATERIALS AND METHODS}

The present study was performed according to the norms of ethics and biosafety of the Colegio de Postgraduados, Campus Montecillo, Mexico.
Animals. The study was conducted from November to May in the experimental farm of the Colegio de Postgraduados, Montecillo Campus. Thirty Dorset x Suffolk cross ewes were distributed in a completely random design in three treatments, T1: primiparous ewes with an average age of 15 months $(n=10)$; when these ewes became pregnant and lactating, they were classified as first parity ewes; T2: ewes that had one parity $(n=10)$, which were classified as second parturition ewes when they became pregnant and lactating; and T3: ewes with $\geq 3$ parturitions $(n=10)$, which were classified as $\geq 4$ parity when they became pregnant and lactating. The animals were vaccinated and wormed at the beginning of the experiment and were kept with their group during the study. They had free access to dehydrated oat forage and 400 grams of concentrate (Table 1). The ewes were pre-synchronized with two dosages of chloprostenol 8 days apart, and 6 days after the second application, an intravaginal device impregnated with progesterone was implemented and left for 11 days. The ewes were bred at estrus onset after withdrawal of the intravaginal device.

Sampling. Ewes were sampled from the jugular vein and blood was collected with $5 \mathrm{~mL}$ tubes with EDTA to obtain plasma. Sampling moments were achieved when they were not pregnant (day 5 of the estrous cycle) in the first, second, third, and fourth months of gestation $(30,60,90$, and 120 days), and on day 143 of gestation, and also on the fifth day and first month (30 days) of lactation. Tubes were centrifuged at $2500 \mathrm{~g}$ for 10 minutes at $4^{\circ} \mathrm{C}$. Plasma was conditioned in cryostat tubes and stored at $-40^{\circ} \mathrm{C}$ until analysis.

Average gestation time was 145 days, therefore samples were collected from ewes on day 143, which was 2 days before parturition. All ewes had only one offspring.

Antioxidant capacity. Total antioxidant capacity was measured using Benzie \& Strain's FRAP (ferric reducing antioxidant power) technique (1996). A mixture was prepared consisting of a buffer solution of $300 \mathrm{mM}$ acetate at $\mathrm{pH} 3.6,20 \mathrm{mM}$ aqueous solution of ferric chloride hexahydrate (Fe III) and 10mM 2,4,6-tripyridyl-s-triazine (TPTZ) (dissolved in $40 \mathrm{mM} \mathrm{HCl}$ ) at a 10:1:1 ratio, respectively. Next, $50 \mu \mathrm{L}$ of sample was added to $1.5 \mathrm{~mL}$ of the mixture. The samples were incubated at $37^{\circ} \mathrm{C}$ for $10 \mathrm{~min}$ and their absorbances were obtained by spectrophotometry at $593 \mathrm{~nm}$. As the standard for calculating the results, 6-hydroxy-2-5-7-8-tetramethyl-chroman-2-carboxylic acid (trolox) was used at different concentrations $(0.2-1.6 \mathrm{mM})$ since it is a water-soluble analogue of vitamin E, which is frequently used in animal production.

Lipoperoxidation. Lipoperoxidation was measured using the thiobarbituric acid reactive substances (TBARS) test, following the procedure described by Ohkawa et al. (1979) with a few modifications. One milliliter of $0.8 \%$ thiobarbituric acid and $2 \mathrm{~mL} 20 \%$ acetic acid, adjusted to $\mathrm{pH} 2.5$, were added to $100 \mu \mathrm{L}$ of plasma. The samples were boiled for $60 \mathrm{~min}$ and later cooled with ice water, and $5 \mathrm{~mL}$ n-butanol (n-butyl alcohol) were added. After shaking vigorously, the samples were centrifuged for $10 \mathrm{~min}$ at $4000 \mathrm{rpm}$. Supernatant absorbance was measured by spectrophotometry at $532 \mathrm{~nm}$. The results were calculated using different

Table 1. Ingredients of the diet administered to ewes during gestation and lactation

\begin{tabular}{lc}
\hline Ingredient & Percentage of the diet \\
\hline Ground maize & 40.72 \\
Ground sorghum & 11.15 \\
Soy paste & 12.08 \\
Maize stover & 30.05 \\
Molasses & 5.00 \\
${ }^{*}$ Mineral salt & 1.00 \\
\hline
\end{tabular}

*Phosphorus (17.5\%), sodium (12.9\%), calcium (5.6\%), magnesium (3.4\%). 
concentrations (1-8mM) of malondialdehyde (MDA), obtained by acid hydrolysis from 1,1,3,3-tetraethoxypropane.

Glutathione peroxidase. To determine the total activity of glutathione peroxidase, the technique of Lawrence \& Burk (1976) was used. Two $100 \mu \mathrm{L}$ aliquots of each sample were taken; 800 $\mu \mathrm{L}$ of a mixture of $50 \mathrm{mM}$ phosphate buffer solution ( $\mathrm{pH} 7.9$ ) with $1 \mathrm{mM}$ EDTA and $1 \mathrm{mM}$ sodium azide, $1 \mathrm{mM}$ GSH (reduced), $1 \mathrm{U} / \mathrm{mL}$ glutathione reductase and $0.2 \mathrm{mM}$ NADPH were added to each sample. Each test was accompanied by a control without sample to rule out non-enzymatic oxidation of NADPH. The tests and controls were incubated at $37^{\circ} \mathrm{C}$ for $5 \mathrm{~min}$; then $100 \mu \mathrm{L} 2.5 \mathrm{mM} \mathrm{H} \mathrm{H}_{2}$ was added. Absorbance was read at $340 \mathrm{~nm}$ at 0 and $5 \mathrm{~min}$. The coefficient of NADPH molar absorption of $6.22 \times 10^{3} \mathrm{M}^{-1} \mathrm{~cm}^{-1}$ was used for the calculations. The results of oxidized NADPH were presented as $\mathrm{nmol} / \mathrm{mL} / \mathrm{min}$.

Ascorbic acid. An ascorbic acid analysis was carried out following the technique described by Jacota \& Dani (1982), with modifications consisting of mixing 10\% trichloroacetic acid and $400 \mu \mathrm{L}$ plasma, shaking vigorously for 5 seconds, incubating for $5 \mathrm{~min}$ in ice water, and finally centrifuging at $3000 \mathrm{rpm}$ for $5 \mathrm{~min}$. Next, $100 \mu \mathrm{L} 10 \%$ folin phenol was added to $1 \mathrm{~mL}$ of supernatant. This was shaken for 3 seconds and incubated at room temperature for $10 \mathrm{~min}$. The reading was performed by spectrophotometry at $760 \mathrm{~nm}$. The curves were constructed with ascorbic acid at concentrations of $0,20,40,80$ and $160 \mu \mathrm{g} \mathrm{mL}-1$.

A UV-V15 spectrophotometer was used for the analyses. All of the analyses of the indicators of oxidative state were done in duplicate.

Statistical analysis. An analysis of variance was performed considering the parity and time sampled as fixed effects. The parity is nestled at the sheep. The number of parturitions was nested to the ewe. The model used was: $Y_{i j k}=\mu+T_{i}+M_{j+} T_{i} M_{j+} A_{k}\left(C_{i}{ }_{+} E_{i j k}\right.$, where:

$\mathrm{Y}_{\mathrm{ijk}}=$ =response of $\mathrm{i}^{\text {th }}$ parturition of the $\mathrm{j}^{\text {th }}$ sampling of the $\mathrm{k}^{\text {th }}$ repetition, $\mu=$ general mean, $T_{i}=$ effect of the $i^{\text {th }}$ parturition, $M_{i}=$ effect of the $j^{\text {th }}$ sampling, $\mathrm{T}_{\mathrm{i}} \mathrm{M}_{\mathrm{j}}=$ effect of the $\mathrm{i}^{\text {th }}$ parturition in the $\mathrm{j}^{\text {th }}$ sampling, $\mathrm{A}_{\mathrm{k}}(\mathrm{j})=$ effect of the $\mathrm{i}^{\text {th }}$ parturition nested to the $\mathrm{k}^{\text {th }}$ ewe, and $\mathrm{E}_{\mathrm{ijk}}=$ experimental error. When a significance of less than 0.05 was detected, a Tukey comparison of means test was applied. The statistical analyses were carried out with SAS (2002) version 9 software.

\section{RESULTS}

\section{Antioxidant capacity}

Antioxidant capacity did not change as an effect of the number of parity of the ewes. It was, however, modified by gestation and lactation $(\mathrm{P}<0.05)$ (Fig.1).

During gestation, the antioxidant capacity of the ewes decreased in months 1 (171.66nmol trolox $\left.\mathrm{mL}^{-1}\right)$ and 2 $\left(146.39 \mathrm{nmol}\right.$ trolox $\left.\mathrm{mL}^{-1}\right)$, relative to the ewes that were not pregnant $\left(227.72 \mathrm{nmol}\right.$ trolox $\left.\mathrm{mL}^{-1}\right)(\mathrm{P}<0.05)$. It increased again, however, in the third $\left(168.29 \mathrm{nmol}\right.$ trolox $\left.\mathrm{mL}^{-1}\right)$ and fourth months $\left(205.11 \mathrm{nmol}\right.$ trolox $\left.\mathrm{mL}^{-1}\right)$ and up to day 143 of gestation $\left(223.25 \mathrm{nmol}\right.$ trolox $\left.\mathrm{mL}^{-1}\right)$. Another reduction in antioxidant capacity $\left(185.36 \mathrm{nmol}\right.$ trolox $\left.\mathrm{mL}^{-1}\right)$ was observed on day 5 of lactation, although it was not as low as the reduction observed in second month of gestation. It later increased after one month of lactation $(256.03 \mathrm{nmol}$ trolox $\mathrm{mL}^{-1}$ ).

\section{Lipoperoxidation}

Lipoperoxidation decreased with the number of parturitions (Table 2), although the difference was significant
$(\mathrm{P}<0.05)$ only between first parity ewes $(4.02 \mathrm{nmol}$ MDA $\mathrm{mL}^{-1}$ ) and those with $\geq 4$ parity (3.49nmol MDA mL ${ }^{-1}$ ).

Oxidation in plasma was also modified by the physiological state of the ewes. This was lower $(\mathrm{P}<0.05)$ on day 143 of gestation, relative to the other periods sampled during gestation and lactation (Fig.2).

\section{Glutathione peroxidase}

Values of total glutathione peroxidase were not affected by number of parity, but they were modified $(\mathrm{P}<0.05)$ by the physiological state of the ewes. The highest values were found in the second month of gestation $(20.33 \mu \mathrm{mol} /$ $\mathrm{NADPH} / \mathrm{min} / \mathrm{L})$ and on day 5 of lactation $(21.18 \mu \mathrm{mol} / \mathrm{NA}-$ $\mathrm{DPH} / \mathrm{min} / \mathrm{L}$ ). In contrast, the lowest values were found in the first $(7.64 \mu \mathrm{mol} / \mathrm{NADPH} / \mathrm{min} / \mathrm{L})$ and third months of gestation $(6.26 \mu \mathrm{mol} / \mathrm{NADPH} / \mathrm{min} / \mathrm{L})$. No defined tendencies were observed in the other sampling periods during gestation and lactation (Fig.3).

\section{Ascorbic acid}

The number of parity did not affect $(\mathrm{P}<0.05)$ ascorbic acid values, although it indicated that levels of ascorbic acid decreased $(\mathrm{P}<0.05)$ from before pregnancy $\left(10.14 \mu \mathrm{g} \mathrm{L}^{-1}\right)$, reaching the lowest values in the third month of gestation $\left(3.99 \mu \mathrm{g} \mathrm{mL}^{-1}\right)$. This is a reduction of approximately $60.4 \%$

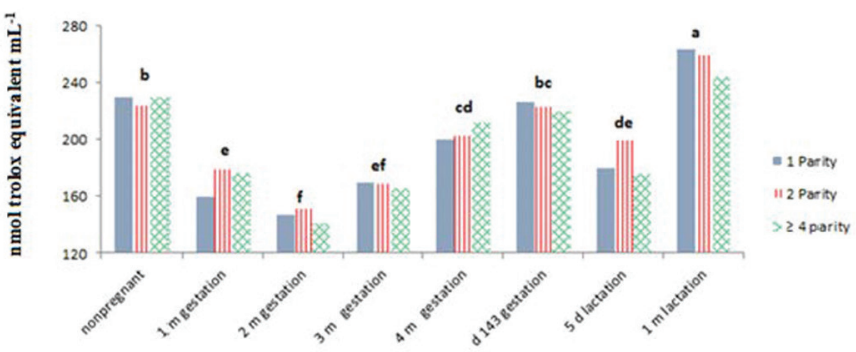

Fig.1. Antioxidant capacity in plasma of ewes with different numbers of parity, measured by the FRAP technique during gestation and lactation.

Table 2. Concentration of malondialdehyde in ewes with different numbers of parity

\begin{tabular}{cccc}
\hline & 1 parity & 2 parity & $\geq 4$ parity \\
\hline nmol MDA mL & $4.02 \pm 0.13^{\mathrm{a}}$ & $3.69 \pm 0.13^{\mathrm{ab}}$ & $3.49 \pm 0.13^{\mathrm{b}}$
\end{tabular}

$\overline{\mathrm{a}, \mathrm{b}}$ Different letters indicate significant differences $(\mathrm{P}<0.05)$.

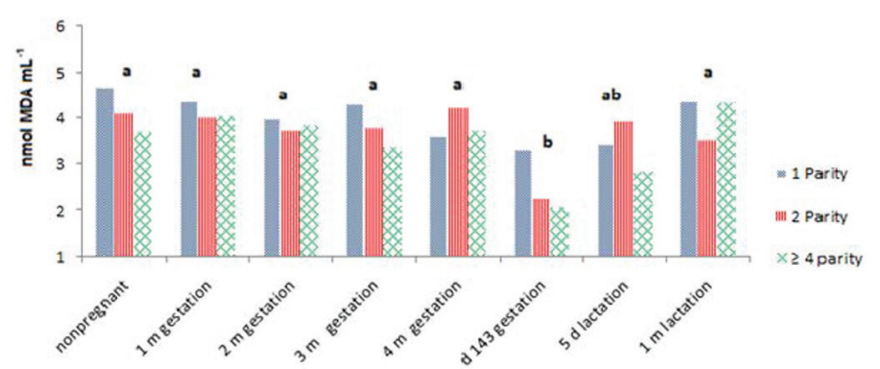

Fig.2. Concentrations of malondialdehyde (MDA) in plasma during gestation and lactation, measured by the TBARS technique in ewes with different numbers of parity. Different letters $(\mathrm{a}, \mathrm{b})$ indicate significant differences $(\mathrm{P}<0.05)$. 


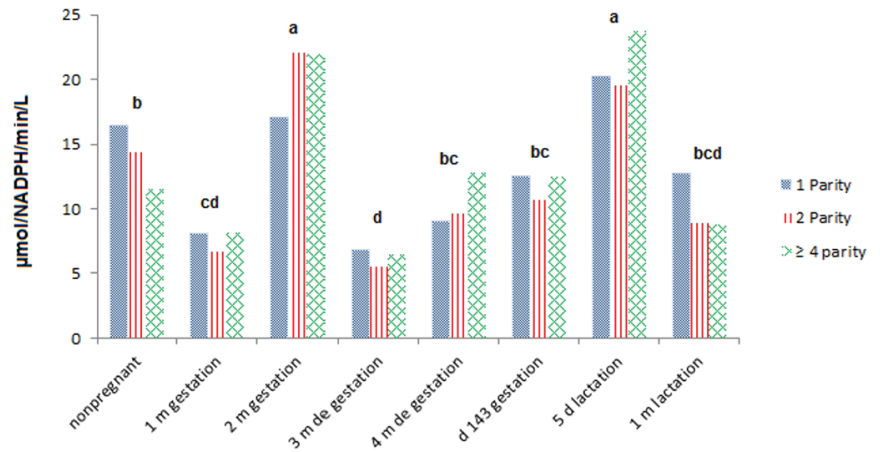

Fig.3. Glutathione peroxidase in plasma of ewes with different numbers of parity during gestation and lactation. Different letters $(\mathrm{a}, \mathrm{b}, \mathrm{c}, \mathrm{d})$ indicate significant differences $(\mathrm{P}<0.05)$.

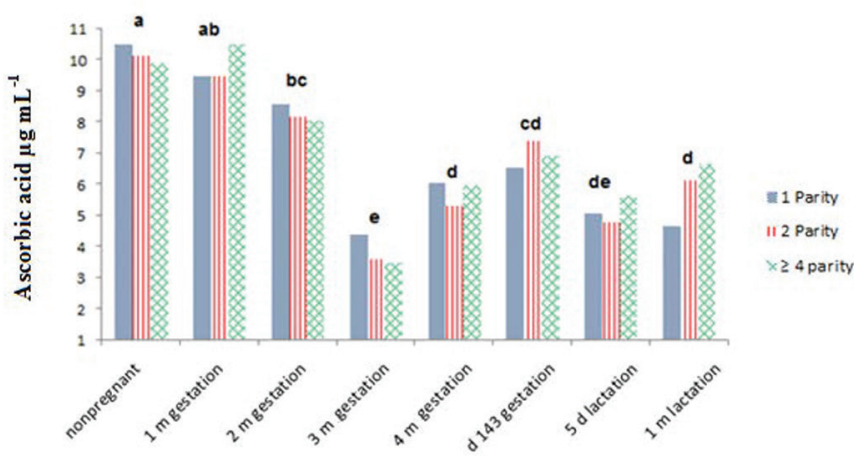

Fig.4. Ascorbic acid in plasma of ewes with different number of parity during gestation and lactation. Different letters (a,b,c,d) indicate significant differences $(\mathrm{P}<0.05)$.

in concentration of vitamin C. After this, there was an increase $(\mathrm{P}<0.05)$ in the fourth month of gestation $\left(5.79 \mu \mathrm{g} \mathrm{mL}^{-1}\right)$ and was even higher on day 143 of gestation $\left(6.95 \mu \mathrm{g} \mathrm{mL}^{-1}\right)$. Although it was not statistically significant $(\mathrm{P}<0.05)$, a second decrease was observed on day 5 of lactation $(5.36 \mu \mathrm{g}$ $\mathrm{mL}^{-1}$, Fig.4).

\section{DISCUSSION}

Antioxidant capacity had two reductions. The first occurred in the second month of gestation, although the decline began from the first month. The second less pronounced than the first, occurred five days after parturition. Turk et al. (2013) found that the antioxidant capacity in dairy cows decreases one week after calving. In contrast, in our study, the ewes had a reduction 5 days after lambing. Kankofer et al. (2010) reported that in cows, the antioxidant capacity increases between four weeks antepartum until five days antepartum with a sharp drop at parturition and another increase after parturition. Likewise, in our study we observed that after the first reduction in antioxidant capacity in the second month of gestation, there was a continual increase up to day 143 of gestation.

Antioxidant capacity is modified in three ways: either via synthesis of antioxidant enzymes, or by altering the way antioxidants are consumed or making a greater use of them. Because all the ewes were fed the same diet during gestation and lactation, the changes could be due to higher use of antioxidants. During gestation, the metabolism of li- pids, which are susceptible to oxidation, is modified (Loy et al. 2013), so it can be assumed that during this period changes take place in the use of antioxidants.

Reduction in antioxidant capacity when ewes are approaching parturition has been reported. Nevertheless, little is known about its decrease during the first two months of gestation when major reproductive events occur, such as implantation, placenta development and hormonal changes. It is necessary to assess the value of antioxidant supplementation and the physiological and reproductive benefits before these decreases occur, given that antioxidant supplementation in the diet has been shown to increase antioxidant capacity in plasma (Liu et al. 2013).

With a higher number of parity, levels of malondialdehyde decreased; that is, as the number of parity increases susceptibility to oxidation decreases. Salar-Amoli \& Baghbanzadeh (2010), however, found higher MDA values in 71 to 90 -month-old ewes than in 10 to 30 -month-old ewes. The difference may be that in our study ewes were used in different stages of gestation and lactation; the antioxidant mechanism in first parturition ewes is not efficient enough to counteract lipid oxidation. In our experiment, MDA values remained relatively stable during gestation and lactation, with the exception of gestation day 143 (3 days before parturition), when a decrease was observed.

In dairy cows, lipid oxidation has been reported to be higher at the end of gestation than in the second and third trimester of gestation (Turk et al. 2008), while Bernabucci et al. (2005), who studied the oxidative state during peripartum, found that oxidation begins increasing 5 days before parturition until it reaches its maximum values 25 days postpartum. In sheep, however, different results have been found. Rezapour \& Taghinejad-Roudbaneh (2011) found that as gestation progresses, lipoperoxidation increases, while Öztabak et al. (2005), measuring MDA values at two moments of gestation, found that oxidation is similar on days 105 and 148. Casamassima et al. (2012) found, when measuring lipid peroxidation concentrations in ewes, that this process increases at parturition. In contrast to indications by all those authors, MDA, which is a peroxidation indicator, did not increase. In ewes pregnant with twins, lipoperoxidation increases (Gür et al. 2011); thus, the increase in metabolism may be the main cause of increases in lipoperoxidation. In our experiment, all of the ewes gave birth to a single offspring.

Glutathione peroxidase (GSh-Px) is an enzymatic antioxidant that catalyzes reduction of hydrogen peroxide into less harmful forms. The highest values were found in the second month of gestation and on day 5 of lactation. These values coincide with the decrease in antioxidant capacity; thus, total GSh-Px activity may have been increasing during the two reductions in antioxidant capacity to prevent lipid oxidation and maintain malondialdehyde levels. The second GSh-Px peak coincides with results of Liu et al. (2013), who reported that GSH-Px concentration increases on days 1 and 7 postpartum, relative to the 21 days pre- and post- partum. Erisir et al. (2009) reported that GSh-Px values are higher in the second and third months of gestation in pregnant ewes. Glutathione peroxidase has been deter- 
mined in different ovarian structures. In the corpus luteum, GSh-Px activity is lower on day 15 than on days $40,60,80$ and 128 (Al-Gubory et al. 2004). Gür et al. (2011) reported that ewes with two fetuses have lower values than ewes with a single fetus or that are not pregnant. In women, glutation activity has been observed to fall in postmenopausal women in comparison to the follicular and luteal (Pejic' et al. 2013). There is also a positive correlation between the peroxidase glutation activity and estradiol (Massafra et al. 2000).

Ascorbic acid concentrations were not modified by the number of parity. The lowest values were found in the third month of gestation. Also, like antioxidant capacity, on day 5 of lactation, a second reduction was observed, although it was less pronounced than the first. This coincides with Kankofer et al. (2010) who found that ascorbic acid decreases at parturition in dairy cows during weeks 4 to 5 of lactation. Although ascorbic acid concentrations increased after the reduction in the third month of gestation, they did not return to those of non-pregnant ewes. The results of our experiment agree with Mohebbi-Fani et al. (2012), who found that concentrations of ascorbic acid and vitamin A on days 1, 7, 21 and 120 of gestation decrease as gestation progresses. However, because of their sampling times, they did not detect the reduction in ascorbic acid concentrations during the third month of gestation, which later increased. In camels, ascorbic acid concentrations are lower during pregnancy than during lactation or when they are not pregnant (Mohamed et al. 2011). Vannucchi et al. (2007) demonstrated that in dogs, the values of vitamin A and E decreased during pregnancy, counteracting oxidative stress. Our study therefore assumes that when vitamin $\mathrm{C}$ decreases during gestation, it is performing the important function of preventing lipid oxidation from increasing to levels of oxidative stress. Olayaki et al. (2008) demonstrated that supplementation with vitamin C during pregnancy reduces MDA concentrations in women. It has been reported that not only in plasma, but also in other reproductive structures, such as sow ovaries, ascorbic acid varies with the estrous cycle and the period of gestation (Petroff et al. 1997). It has been demonstrated that, although ewes are able to synthesize ascorbic acid, during gestation and lactation the concentration is reduced; thus it is necessary to determine whether this reduction is due to its synthesis or to an increase in its utilization and what the probable benefits of supplementation are.

\section{CONCLUSIONS}

It is concluded that the number of parity did not modify the antioxidant capacity, nor glutathione peroxidase or ascorbic acid activities.

Susceptibility to oxidation, however, decreased with the number of parity, suggesting that there is a still unknown mechanism that decreases lipoperoxidation in ewes that have had several parturitions.

Vitamin C and antioxidant capacity showed two reductions in concentration, the first from the beginning of gestation, and the second on day 5 of lactation.
Therefore, further study is necessary to determine the importance of antioxidant supplementation on these specific times, since glutathione peroxidase activity increased in these reductions, possibly to avoid lipidic lipoperoxidation.

Acknowledgments.- The authors wish to thank the partial funding to this research to Linea Prioritaria de Investigación, LPI-11 from the Colegio de Postgraduados and the project DGAPA/PAPIIT: IT222611-3 of the Universidad Nacional Autónoma de México.

\section{REFERENCES}

Al-Gubory K.H., Bolifraud P., Germain G., Nicole A. \& Ceballos-Bicot I. 2004. Antioxidant enzymatic defense systems in sheep corpus luteum throughout pregnancy. Reproduction 128:767-774.

Al-Gubory K.H., Fowler P.A. \& Garrel C. 2010. The roles of cellular reactive oxygen species, oxidative stress and antioxidants in pregnancy outcomes. Int. J. Biochem. Cell Biol. 42:1634-1650.

Agarwal A., Gupta S. \& Sikka S. 2006. The role of free radicals and antioxidants in reproduction. Curr. Opin. Obstet. Gynecol. 18:325-332.

Arthur J.R. 2000. The glutathione peroxidases. Cell. Mol. Life Sci. 57:18251835.

Benzie I.F. \& Strain J.J. 1996. The ferric reducing ability of plasma (FRAP) as a measure of "antioxidant power": The FRAP assay. Analytical Biochem. 239:70-76.

Bernabucci U., Ronchi B., Lacetera N. \& Nardone A. 2005. Influence of body condition score on relationships between metabolic status and oxidative stress in periparturient dairy cows. J. Dairy Sci. 88:2017-2026.

Bouwstra R.J., Nielen M., Newbold J.R., Jansen E.H.J., Jelinek H.F. \& Van Werven T. 2010. Vitamin E supplementation during the dry period in dairy cattle. Part II: Oxidative stress following vitamin E supplementation may increase clinical mastitis incidence postpartum. J. Dairy Sci. 93:5696-5706.

Brzezinska-Slebodzinsk E., Miller J.K., Quigley J.D. \& Moore J.R. 1994. Antioxidant status of dairy cows supplemented prepartum with vitamin $\mathrm{E}$ and selenium. J. Dairy Sci. 77:3087-3095.

Casamassima D., Palazzo M., Martemucci G., Vizzarri F. \& Corino C. 2012. Effects of verbascoside on plasma oxidative status and blood and milk production parameters during the peripartum period in Lacaune ewes. Small Ruminant Res. 105:1-8.

Celi P., Di Trana A. \& Claps S. 2010. Effects of plane of nutrition on oxidative stress in goats during the peripartum period. Vet. J. 184:95-99.

Erisir M., Benzer F. \& Kandemir F.M. 2009. Changes in the rate of lipid peroxidation in plasma and selected blood antioxidants before and during pregnancy in ewes. Acta Vet. Brno. 78:237-242.

Gür S., Türk G., Demirci E., Yüce A., Sönmez M., Özer S. \& Aksu E.H. 2011. Effect of pregnancy and foetal number on diameter of corpus luteum, maternal progesterone concentration and oxidant/antioxidant balance in ewes. Reprod. Domest. Anim. 46:289-295.

Kamiloğlu N.N., Beytu E., Güven A. \& Altinsaat C. 2006. Changes in the erythrocyte anti-oxidant system of offspring of dams treated with vitamin A and carotene during gestation. Small Ruminant Res. 65:142148.

Kankofer M., Albera E., Feldman M., Gundling N. \& Hoedeamker M. 2010. Comparison of antioxidative/oxidative profiles in blood plasma of cows with and without retained fetal placental membranes. Theriogenology 74:1385-1395.

Lawrence R.A. \& Burk R.F. 1976. Gluthatione peroxidase activity in selenium-deficient rat liver. Biochem. Biophys. Res. Commun. 71:952-958.

Liu H.W., Zhou D.W. \& Lit K. 2013. Effects of chestnut on performance and antioxidative status of transition dairy cows. J. Dairy Sci. 96:5901-5907.

Loy S.L., Sirajudeen K.N.S. \& Jan J.M.H. 2013. Increase in maternal adiposity and poor lipid profile is associated with oxidative stress markers during pregnancy. Prev. Med. 57:S41-S44.

Massafra C., Gioia D., De Felice C., Picciolini E., De Leo V., Bonifazi M. \& Bernabei A. 2000. Effects of estrogens and androgens on erythrocyte 
antioxidant superoxide dismutase, catalase and glutathione peroxidase activities during the menstrual cycle. J. Endocrinol. 167:447-452.

Mohamed H.E., Alhaidary A. \& Beynen A.C. 2011. Ascorbic acid status of female camel during different phases of reproduction. Trop. Anim. Health Prod. 43:279-281.

Mohebbi-Fani M., Mirzaci A., Nazifi S. \& Shabbooie Z. 2012. Changes of vitamins $\mathrm{A}, \mathrm{E}$, and $\mathrm{C}$ and lipid peroxidation status of breeding and pregnant sheep during dry seasons on medium-to-low quality forages. Trop. Anim. Health Prod. 44:259-265.

Olayaki L.A., Ajao S.M., Jimoh G.A.A., Aremu I.T. \& Soladoye A.O. 2008. Effect of vitamin $\mathrm{C}$ on malondialdehyde (MDA) in pregnant nigerian women. J. Basic Appl. Sci. 4:105-108.

Ohkawa H., Ohishi N. \& Yagi K. 1979. Assay for lipid peroxides in animal tissues by thiobarbituric acid reaction. Analytical Biochem. 95:351-358.

Öztabak K., Civelek S., Özpinar A., Burçk A. \& Esen F. 2005. The effects of energy restricted diet on the activities of plasma Cu-Zn SOD, GSH-Px, CAT and TBARS concentrations in late pregnant ewes. Turk. J. Vet. Anim. Sci. 29:1067-1071.

Pedernera M., Celi P., García S.C., Salvin H.E., Barchia I. \& Fulkerson W.J. 2010. Effect of diet, energy balance and milk production on oxidative stress in early-lactating dairy cows grazing pasture. Vet. J. 186:352-357.

Pejic' S.A., Jelena D.K., Todorovic' A.U., Stojiljkovic' V.R., Gavrilovic' L.V., Popovic' N.M. \& Pajovic S.B. 2013. Antioxidant enzymes in women with endometrial polyps: relation with sex hormones. Eur. J. Obstet. Gynecol. Reproduct. Biol. 170:241-246.

Petroff B.K., Dabrowski K., Ciereszko R.E. \& Ottobre J.S. 1997. Total ascorbate and dehydroascorbate concentrations in porcine ovarian stroma, follicles and corpora lutea throughout the estrous cycle pregnancy. Theriogenology 47:1265-1273.

Rezapour A. \& Taghinejad-Roudbaneh M. 2011. Effects of food restriction on oxidative stress in ghezel ewes. J. Anim. Vet. Adv. 10:980-986.

Salar-Amoli J. \& Baghbanzadeh A. 2010. Oxidative stress in shaal sheep of different age groups. Turk. J. Vet. Anim. Sci. 34:379-383.

SAS 2002. SAS Proceeding Guide, versión 9. Statistical Analisys System, SAS Institute, Cary NC, USA.

Turk R., Juretić D., Gereš D., Svetina A., Turk N. \& Flegar-Meštrić Z. 2008. Influence of oxidative stress and metabolic adaptation on PON1 activity and MDA level in transition dairy cows. Anim. Reprod. Sci. 108:98106.

Turk R., Podpečan O., Mrkun J., Kosec M., Flegar-Mestrić Z., Perkov S., Starič J., Robić M., Belić M. \& Zrimsek P. 2013. Lipid mobilization and oxidative stress as metabolic adaptation processes in dairy heifers during transition period. Anim. Reprod. Sci. 141:109-115.

Vannucchi C.I., Jordao A.A. \& Vannucchi H. 2007. Antioxidant compounds and oxidative stress in female dogs during pregnancy. Res. Vet. Sci. 83: 188-193. 